\title{
底開・全開バージによる土砂投入形状の 現地比較実験 \\ FIELD EXPERIMENT ON DEPOSITION CONFIGURATION OF EARTH-SAND DUMPED FROM HOPPER AND SPLIT BARGES
}

\author{
荒井清 1 ・太田正規 1 -五明美智男 $2 \cdot$ 矢内栄二 3 - 松見吉晴4 \\ Kiyoshi ARAI, Masanori OTA, Michio GOMYO, Eiji YAUCHI and Yoshiharu MATSUMI \\ ${ }^{1}$ 正会員 工修 東亜建設工業侏）大阪支店（二596-0015 大阪府岸和田市地藏浜11-1） \\ 2正会員 水修 東亜建設工業侏 技術研究所（广230-0035 横浜市鶴見区安善町 $1-3$ ) \\ 3 正会員 工博 東亜建設工業(侏) 土木本部設計部（广102-8451 東京都千代田区四番町 5) \\ 4 正会員 工博 鳥取大学工学部 社会開発システム工学科（テ680-0946 鳥取市湖山町南4-101）
}

\begin{abstract}
Hopper and split barges are frequently used in marine construction schemes for reclamation of offshore land for airports and caisson foundations. In order to realize a designed geometry accurately and effectively, the deposition configuration of earth and sand dumped by barges and the optimum interval of discharge sites of barges for a specified degree of uniformity in the mound surface must be predicted in advance.

In the present study, a sailing arrangement system based on a prediction model was used in a construction project. It was confirmed by field engineers that the deposition configuration of earth and sand dumped by a hopper barge is different from that of earth and sand dumped by a split-type barge. The characteristics of the spatial deposition configurations resulting from dumping by each type of barge were investigated under the condition of a single discharge of earth and sand in field experiments
\end{abstract}

Key Words : Hopper barge, split barge, sand dump, deposition configuration, field experiment

\section{1. はじめに}

海面から土砂を投入する方法として, 底開式バー ジおよび全開式バージがしばしば使用される(図-1). 著者らは,これらの土運船を用いた効率的な土砂投 入管理を目的として, リアルタイム地形計測と堆積 形状予測モデルを組み合わせた配船位置管理システ ムについて研究を行ってきた ${ }^{1)-4)}$. その結果, 底開 式と全開式バージでは投入後の堆積形状も異なるこ とが現場技術者から指摘されるようになってきたが, 従来の研究ではこの点について明確に検討されたも のはほとんどなく, 配船位置管理システム運用上の

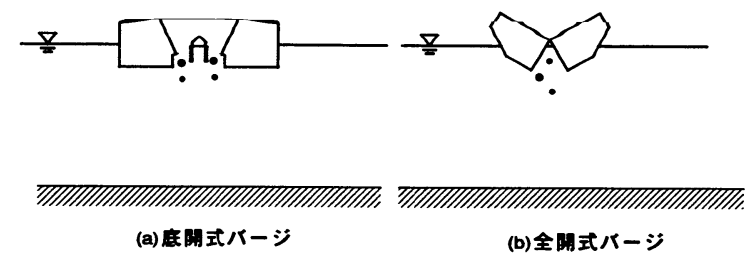

图-1 底開式および全開式バージ
問題となってきている.

本研究では, 同一海域において実施された底開式 と全開式バージの直投による堆積形状を現地調査に より比較し, それらの特徵について検討する.

\section{2. 調査内容}

\section{（1）調査地点と項目}

現地調查は, 兵庫県神戸市において実施されてい る「六甲南フェニックス」工事の水深 $14 \mathrm{~m}$ の海域に おいて行った. サンドドレーンにより改良された軟 弱地盤上およびその周辺に厚さ $1 \mathrm{~m}$ の盛砂をして, その上に底開式あるいは全開式バージにより土砂の 直接投入を実施している(図-2). 投入上砂の中央粒 径 $\mathrm{d}_{50}=30 \mathrm{~mm}$ であり, 底開式バージは表-1に示すよう に $3,200 \mathrm{~m}^{3}$ 積み 1 隻および $5,000 \mathrm{~m}^{3}$ 積み 2 隻と, 全開 式バージとして $3,000 \mathrm{~m}^{3}$ 積み 1 隻および $3,500 \mathrm{~m}^{3}$ 積み 3 隻, 合計 7 隻の土運船を使用した.

投入した土砂の堆積形状は, 事前事後に東亜建設 工業(姝で開発されたGPS とナローマルチビーム探査 ソナーおよび動摇補正装置を組み合わせたリアルタ 


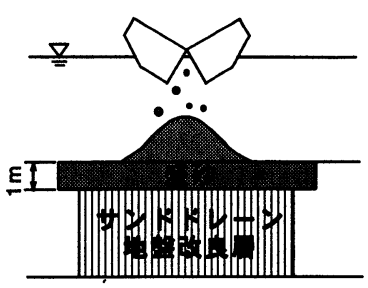

図-2 投入概念図

表-1 バージ諸元

\begin{tabular}{|c|c|c|c|c|c|}
\hline \multirow{2}{*}{\multicolumn{2}{|c|}{ 諸 元 }} & \multicolumn{2}{|c|}{ 底 開 式 } & \multicolumn{2}{|c|}{ 全 開 式 } \\
\hline & & $\mathrm{A}$ & $\mathrm{B}, \mathrm{C}$ & $\mathrm{D}, \mathrm{E}, \mathrm{F}$ & G \\
\hline \multicolumn{2}{|c|}{ 積載量 $\left(\mathrm{m}^{3}\right)$} & 3,200 & 5,000 & 3,500 & 3,000 \\
\hline \multicolumn{2}{|c|}{ 全長(m) } & 99 & 122 & 101 & 78 \\
\hline \multicolumn{2}{|c|}{ 幅(m) } & 20 & 22 & 19 & 19 \\
\hline \multirow{4}{*}{$\begin{array}{l}\text { 土槽 } \\
\text { (m) }\end{array}$} & 長さ & 66 & 98 & 56 & 54 \\
\hline & 幅 & 11.6 & 13.5 & 13.9 & 15.0 \\
\hline & 深さ & 6.4 & 6.5 & 6.5 & 5.8 \\
\hline & 開口幅 & 3.4 & 3.6 & 8.5 & 4.7 \\
\hline \multirow{2}{*}{$\begin{array}{c}\text { 吃水 } \\
\text { (m) }\end{array}$} & 満載 & 4.7 & 5.0 & 4.8 & 4.5 \\
\hline & 空船 & 1.7 & 1.4 & 1.2 & 1.3 \\
\hline
\end{tabular}

イム地形計測システム (ベルーガシステム)を用いて 測定した. 施工条件として, 潮位, 潮流速度および 流向，風速・風向，投入位置より $50 \mathrm{~m}$ 離れた位置で の流速, 投入所要時間を測定した.

\section{(2) 沈下量の測定}

土砂投入によって生じる沈下量(めりこみ量)とし て, 底開バージのAと全開バージのDについて, 地 盤改良部分における投入前後の地盤高変化を計測し た.

計測には図-3に示すSEP台船を用い, 電気式静的 コーン貫入試験装置による先端抵抗の変化から地盤 の変化を読みとった.

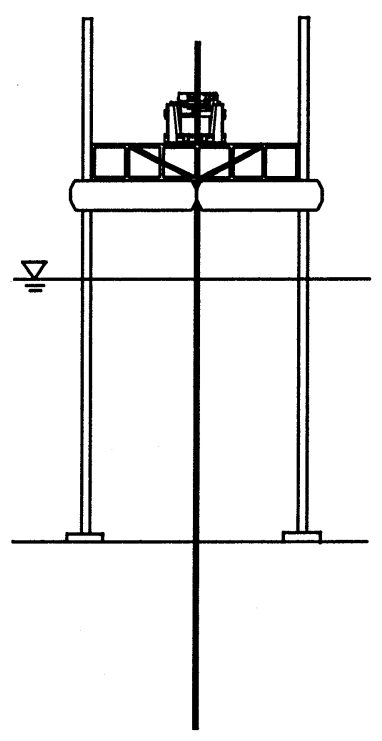

図-3 沈下量測定方法

\section{3. 計測結果と考察}

（1）堆積形状

表-2に投入状況の結果を示す．表中の投入時間は 土槽内から土砂が排出終了するまでの時間である.

図-4は，代表的なケースにおける底開・全開それ ぞれのバージによる堆積形状の鳥瞰図を示したもの であるが，底開式・全開式いずれについても大きな 二つの山が形成されている状況が認められる.

図-5〜11は, 各バージにおける投入前後の深浅値

表-2 投入状況調査結果

\begin{tabular}{|c|c|c|c|c|c|c|}
\hline 船名 & 種類 & $\begin{array}{l}\text { 積載 } \\
\left(\mathrm{m}^{3}\right)\end{array}$ & $\begin{array}{c}\text { 投入時間 } \\
\text { (s) }\end{array}$ & 地盤 & $\begin{array}{l}\text { 流速 } \\
(\mathrm{m} / \mathrm{s})\end{array}$ & $\begin{array}{l}\text { 風速 } \\
(\mathrm{m} / \mathrm{s})\end{array}$ \\
\hline \multirow{5}{*}{ A } & \multirow{7}{*}{ 底開 } & 3,194 & 26 & 改 & 0.20 & 4.0 \\
\hline & & 3,168 & 24 & 未 & 0.05 & 1.0 \\
\hline & & 3,181 & 22 & 末 & 0.40 & 9.0 \\
\hline & & 3,172 & 20 & 改 & 0.15 & 3.0 \\
\hline & & 3,167 & 20 & 末 & 0.20 & 8.0 \\
\hline B & & 3,594 & 15 & 改 & 0.05 & 3.0 \\
\hline C & & 4,841 & 14 & 改 & 0.05 & 2.0 \\
\hline \multirow{3}{*}{ D } & \multirow{6}{*}{ 全開 } & 2,315 & 118 & 末 & 0.15 & 1.0 \\
\hline & & 2,601 & 105 & 末 & 0.20 & 7.0 \\
\hline & & 2,831 & 100 & 末 & 0.30 & 4.0 \\
\hline $\mathrm{E}$ & & 2,680 & 173 & 末 & 0.10 & 6.0 \\
\hline $\mathrm{F}$ & & 2,658 & 158 & 末 & 0.10 & 8.0 \\
\hline G & & 2,418 & 80 & 末 & 0.15 & 3.0 \\
\hline
\end{tabular}

"改 : サンドドレーン改良部投入，未 : 未改良部投入

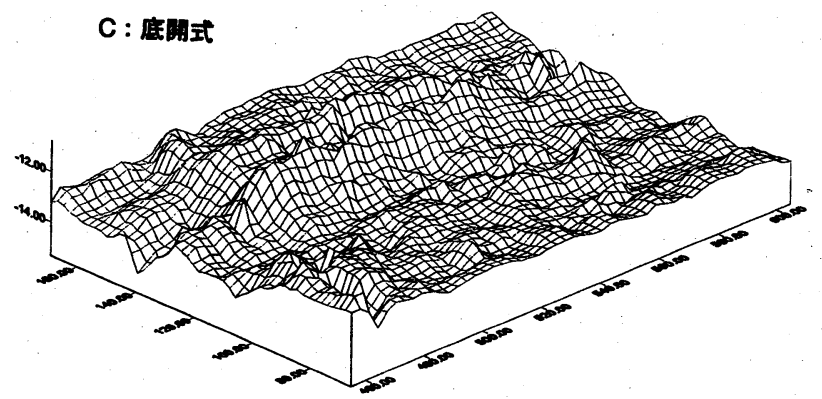

(a) 底開バージ

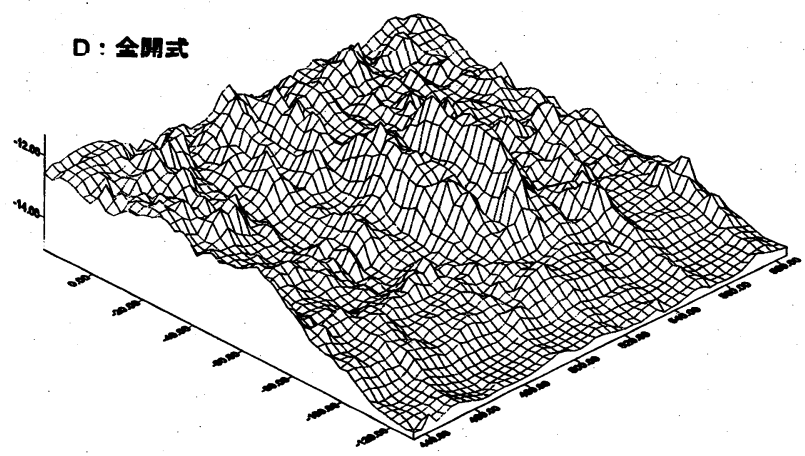

(b) 全開バージ

图-4 堆樌状況鳥瞰图 


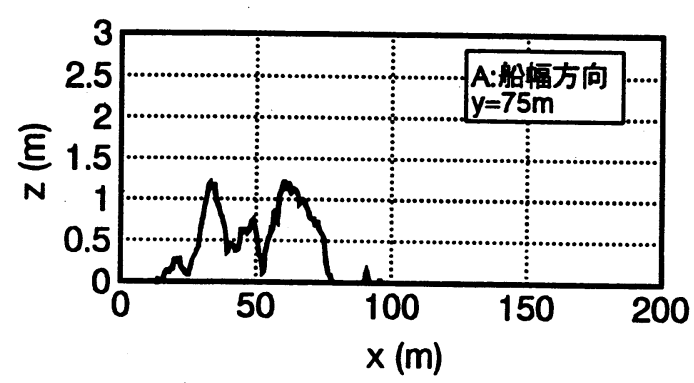

(a) 船幅方向

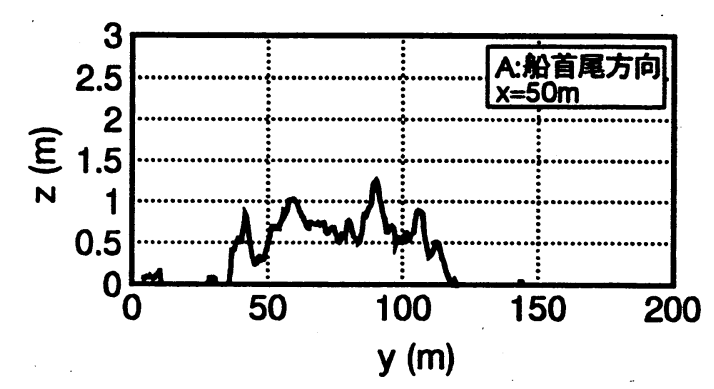

(b)船首尾方向

图-5 堆程形状（底開A）

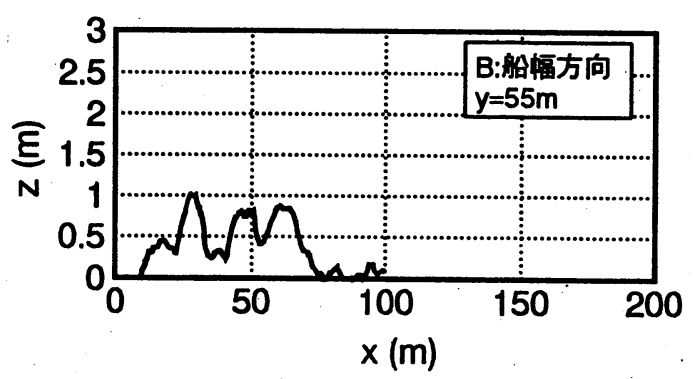

（a）船幅方向

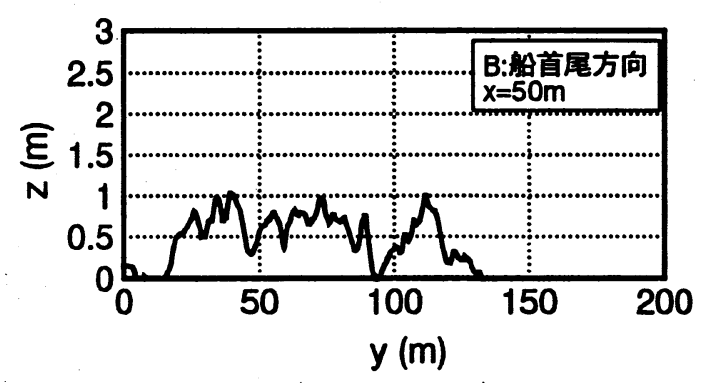

(b)船首尾方向

図-6 堆䅡形状（底開B）

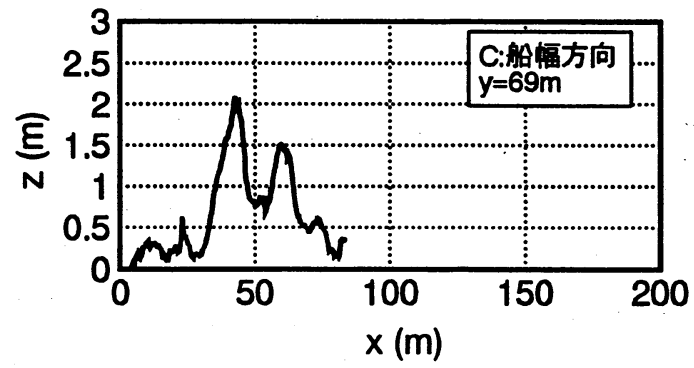

(a)船幅方向

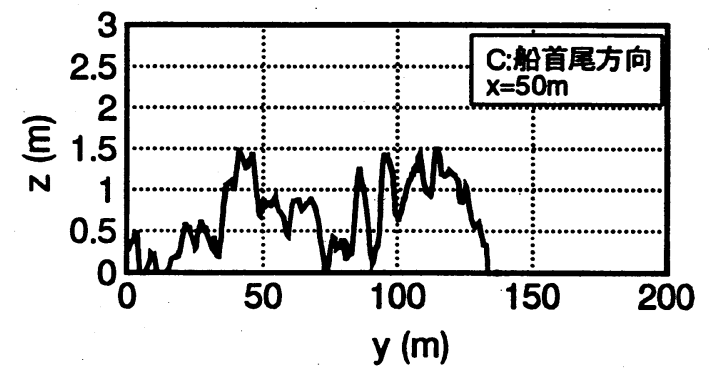

(b)船首尾方向

図-7 堆程形状（底闰C）

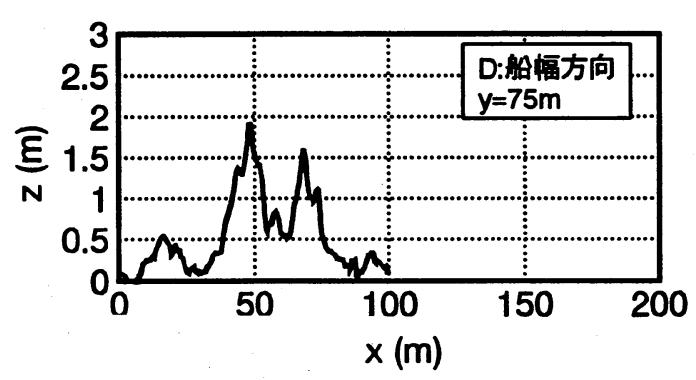

（a）船湢方向

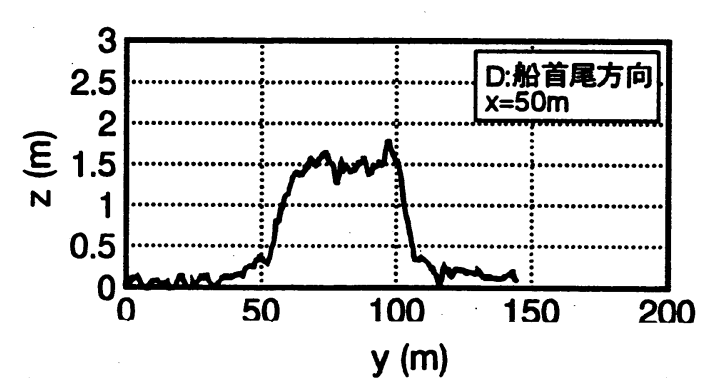

(b)船首尾方向

图-8 堆程形状（全開D）

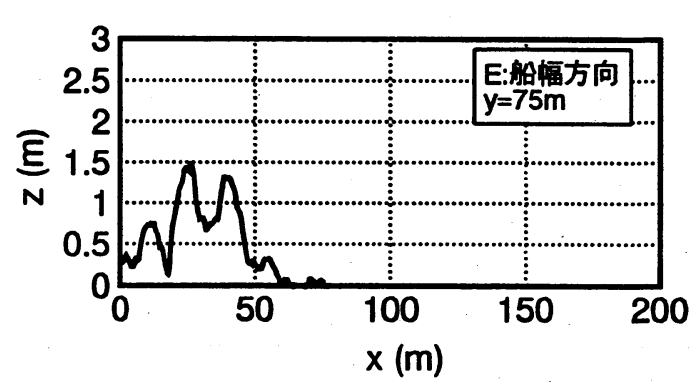

(a) 船愊方向

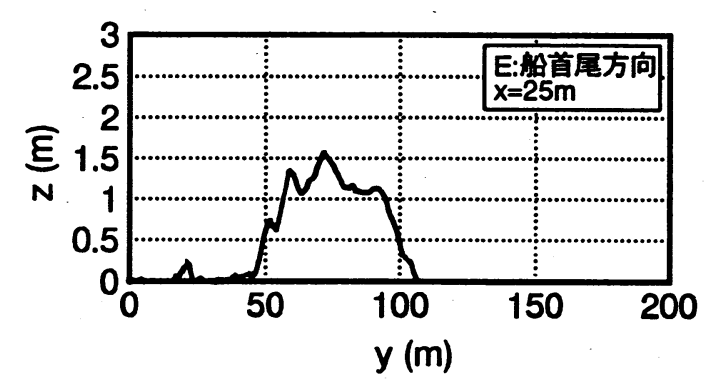

(b)船首尾方向

图-9 堆㮴形状（全荓E） 


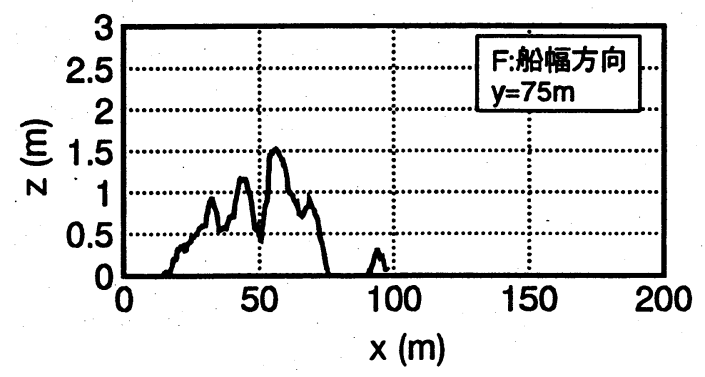

（a）船幅方向

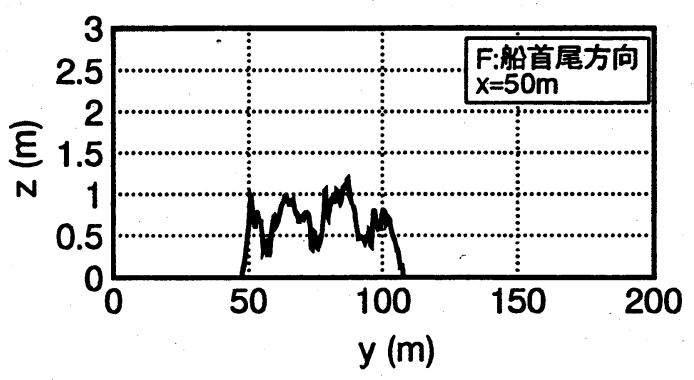

(b) 船首尾方向

図-10堆積形状（全開F）

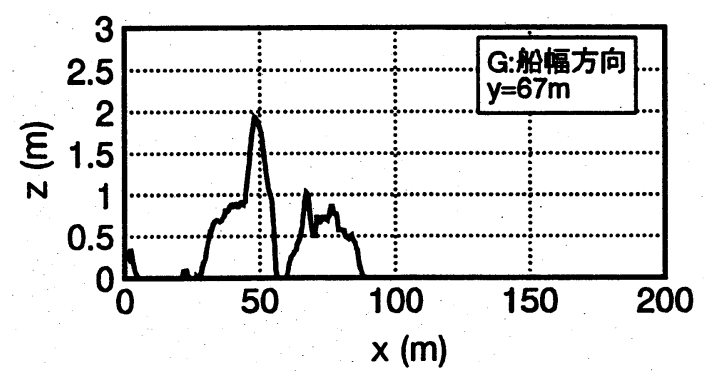

（a）船幅方向

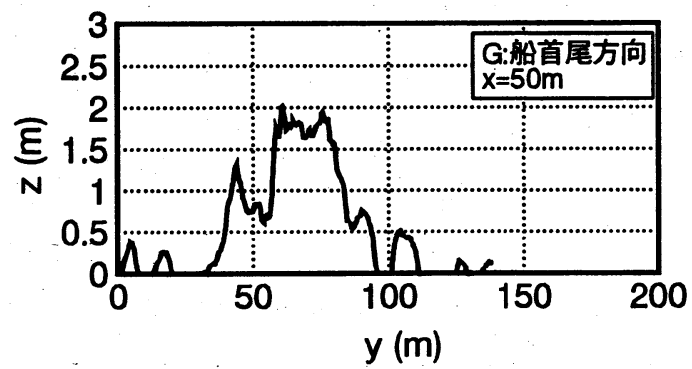

(b) 船首尾方向

図-11 堆積形状(全開G)

の差分から，堆積中央部の断面形状を算出したもの である.（a)は船幅方向，(b)は船首尾方向であり， 凡例中の座標値はそれぞれの切り出し座標を示して いる.

底開バージ(図-5〜7) および全開バージ（図-8〜 11)のすべてのケースにおいて, 船幅方向には二山 型の堆積形状が, 船首尾方向には一山型の堆積形状 が認められる。

底開バージによる堆積形状 (図-5〜7) の特徴とし て, 船首尾方向の堆積幅が長く, 堆積高さの変動幅 も $20 \mathrm{~cm}$ 前後と比較的大きいことがあげられる.

图-8〜11は, 全開バージの堆積形状である. 全開 バージの場合, 船首尾方向の堆積幅が $50 \mathrm{~m}$ 程度の変 動の少ない山型を形成することが特徵的である. 船 幅方向の堆積形状で見ると, 底開バージの結果と異 なり二山の脇に小さな山があるが, これは全開バー ジでは投入までに要する時間が長く，風や流れによ り船体が移動したことによる堆積と考えられる. 表 -2に示したように，今回の調査では全開バージによ る投入の際には特に風が強く，土砂投入中に15〜 20mもバージ船体が移動したケースもあった。図10 (a)の全開バージFのケースで明瞭な二山が現れて いないのは, このような理由によるものと考えられ る.

堆積形状の違いとして, 二山の頂部幅と頂部高さ について検討する. 図-12は, 二山の頂部幅B之頂 部高Dの関係を示したものである，底開式は頂部間 隔の分散幅が大きく, また全開式よりも頂部間隔が 大きい. 同一の頂部幅で比較すると, 全開式は底開 式よりも頂部高さが大きくなる傾向が見られる. ま

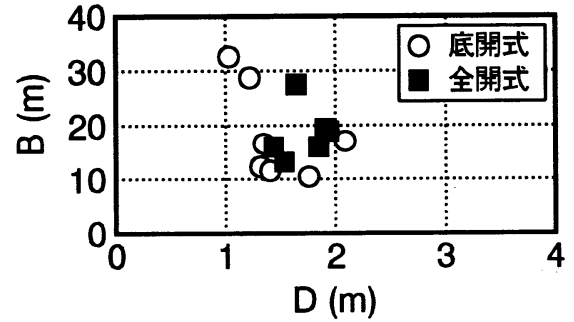

図-12 頂部間隔Bと頂部高D

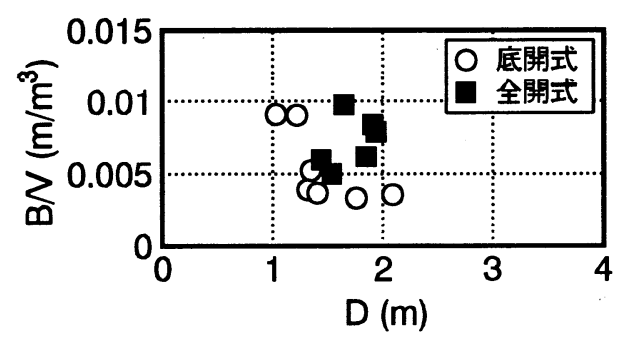

図-13 単位土量あたりの頂部間隔と頂部高

た，底開式は頂部高さが大きくなると頂部間隔が小 さくなる傾向が見られるが, 全開式の場合には特徵 的な傾向が認められない. ただし，このときの底開 式と全開式とでは $1000 \mathrm{~m}^{3}$ 前後も投入土量が異なっ ている. そこで，二山の頂部幅を投入土量Vで割っ たものと頂部高Dの関係を示したものが図-13であ る.このときの結果でも, 底開式の場合には頂部高 さが大きくなると頂部間隔が小さくなる傾向が見ら れるが，全開式の場合には特徴的な傾向が認められ ない. 


\section{(2) 沈下量}

表-3に静的コーン貫入試験により測定された敷砂 面の沈下量を示す．ここで, 測定位置は図-14に示 すように投入時の衝撃が最も大きいと考えられた二 山の中央部である.

その結果，投入による敷砂面の沈下量は，3cm〜 $18 \mathrm{~cm}$ となり, 比較的小さな值となった.この理由 については現在室内実験により検討中であるが, 投入位置直下では衝撃によるめりこみはあまり大き くなく, むしろ堆積後の静的な荷重によって沈下し ていくものと考えられる.

\section{表-3 静的コーン貫入試験結果}

\begin{tabular}{|c|c|c|c|c|}
\hline \multirow{2}{*}{ 船名 } & \multirow{2}{*}{ 測点 } & \multicolumn{2}{|c|}{ 地盤高(m) } & \multirow{2}{*}{$\begin{array}{c}\text { 沈下量 } \\
\text { (m) }\end{array}$} \\
\hline & & 投入前 & 投入後 & \\
\hline \multirow{3}{*}{ 全開D } & 3 & -13.28 & -13.31 & 0.03 \\
\hline & 4 & -13.27 & -13.45 & 0.18 \\
\hline & 5 & -13.18 & -13.24 & 0.06 \\
\hline \multirow{4}{*}{ 底開A } & 6 & -12.28 & -12.32 & 0.04 \\
\hline & 7 & -12.48 & -12.57 & 0.09 \\
\hline & 8 & -12.51 & -12.56 & 0.05 \\
\hline & 9 & -12.45 & -12.45 & 0 \\
\hline
\end{tabular}
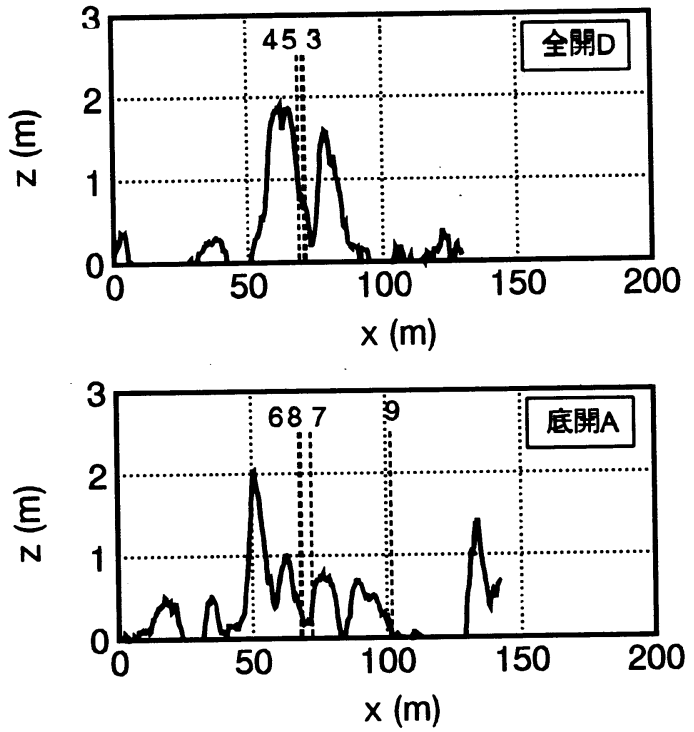

图-14 沈下量測点

\section{（3）配船位置管理システムへの適用}

以上の結果から，配船位置管理システムで投入モ デル ${ }^{3)}$ を使用するにあたっては，下記の項目を考慮 する必要があることがわかった.

(1) 二山頂部間隔

全開式バージは底開式バージよりも土砂が集中す る傾向があることがわかった. その理由として, 全 開式バージは油圧方式により扉が開くにつれて少し ずつ投入するのに対し，底開式ではヒンジをはずす
ことにより瞬時に投入するため大きなエネルギーを 持って投入することによるものであると考えられる. (2) バージ船体の移動

底開式バージとの投入方法の違いにより, 全開式 バージでは風や流れの影響を受けやすい. 対象水深 や土量によっては，バージ船体が移動することを考 慮する必要がある.

\section{3. むすび}

堆積形状については，底開式・全開式いずれにつ いても「二山型」となった. しかし，二山の頂部幅 は全開式よりも底開式の方が大きくなり, 堆積厚は 全開式が底開式よりも大きくなる傾向がみられた。 このことから, 全開式バージは底開式バージよりも 土砂が集中する傾向があることがわかった. その理 由として, 全開式バージは油圧方式により扉が開く につれて少しずつ投入するのに対し，底開式ではヒ ンジをはずすことにより瞬時に投入するため大きな エネルギーを持って投入することによるものである と考えられる.

流れの影響については，上記に述べた投入方法の 違いにより全開式バージでは流れの影響を受けやす いが, 底開式バージではこの程度の水深ではほとん ど流れの影響を受けないことがわかった。

謝辞 : 本調査の実施にあたり快く承認を頂いた大阪 湾広域臨海環境・整備センターの方々に謝意を表す る. また, 深浅データの取得・解析にあたっては東 亜建設工業侏機電部の方々の協力を得た．併せて謝 意を表する.

\section{参考文献}

1) 矢内栄二・横堀浩一・松見吉晴 : トレミー管および全 開バージによる投入土砂の堆積形状, 海洋開発論文集, Vol.13,pp.369-373, 1997.

2) 松見吉晴・矢内栄二・荒井清・増田稔 : 底開式バージ による投入土砂の堆積形状に関する予測モテルの検証 実験, 土木学会第52回年次学術講演会講演概要集 VI, pp.46-47, 1997.

3) 松見吉晴 - 荒井清 -太田正規 - 矢内栄二 ・増田稔 : 軟 弱底面上に投入した土砂の堆積形状とその予測, 海岸 工学論文集, 第45巻, pp.891-895, 1998.

4) 矢内栄二・太田正規・松見吉晴 : 確率モデルを用いた 土砂堆積形状予測計算におけるパラメー夕設定法, 土 木学会第53回年次学術講演会講演概要集 II, pp.168-169, 1998.

5) 武藤碩夫・吉井総介・石田勉 : 大規模埋立用底開バー ジによる土砂投下の研究, 三菱重工技報, Vol.11, No.1, pp.92-104, 1974.

(1999.4.19受付) 